\title{
Enterocholelith in an Appaloosa mare
}

\author{
Claudia Kleiber, Andrea Imhof, Reto Straub, Gottlieb Ueltschi ${ }^{1}$ and Hanspeter Meier \\ Department of Clinical Veterinary Medicine, Equine Clinic (Kleiber, Imhof, Straub and Meier) and Department of Clinical Radiology \\ University of Berne, Berne; Switzerland
}

\begin{abstract}
Summary
A 15 year old appaloosa mare was referred to the equine clinic with signs of hepatic insufficiency. Serum biochemical findings included hyperbilirubinemia and elevated activities of most of the liver specific enzymes. The ultrasound examination of the liver revealed several dilated hepatic ducts. Within one of these an echogenic structure was visualized and interpreted as cholelith. Based on these findings the diagnosis cholelithiasis/ cholangitis causing hepatic insufficiency was made. After ten days of therapy with steroids and six days of therapy with antibiotics respectively, the mare left the clinic in good general condition. Three years later the mare was again referred to the clinic showing the same acute symptoms of hepatic insufficiency and elevated serum activities of the liver specific enzymes. At first she responded well to the steroid therapy but after six days she started to suffer from laminitis and therefore was euthanized. The post mortem examination revealed a markedly dilated common bile duct $(\varnothing 7 \mathrm{~cm})$, which was obstructed by an orange coloured, smooth - fibrous textured cholelith of loamy consistence. The analysis by infrared spectrography revealed that the concrement had the same composition as feces. Unlike the majority of the calculi in horses no mineral components could be detected. As for the ethiopathogenesis we hypothesize that the cholelith formation through reflux of ingesta into the biliary system (therefore its name "enterocholelith") was the underlying problem and the cholangitis and the hepatic insufficiency the consecutive problem.
\end{abstract}

Keywords: enterocholelith, composition of feces, cholangitis, hepatic insufficiency, steroid therapy

\section{Enterocholelith bei einer Appaloosa-Stute}

Eine 15 jährige Appaloosa Stute wurde mit Symptomen einer hepatischen Insuffizienz an die Pferdeklinik überwiesen. Die Blutuntersuchung ergab eine Hyperbilirubinämie und erhöhte Werte der leberspezifischen Enzyme. Bei der sonographischen Untersuchung der Leber waren mehrere dilatierte Gallengänge zu erkennen. In einem davon konnte eine echogene Struktur dargestellt werden, die als Cholelith interpretiert wurde. Basierend auf den Untersuchungsergebnissen lag die Verdachtsdiagnose einer Cholelithiasis/ Cholangitis mit sekundärer Leberinsuffizienz nahe. Dank der Therapie mit Steroiden und Antibiotika besserte sich der Allgemeinzustand der Stute, so dass sie 10 Tage nach Überweisung entlassen werden konnte. 3 Jahre später wurde die Stute mit denselben Symptomen und klinisch-chemischen Veränderungen im Blut an die Pferdeklinik eingeliefert. Sie sprach zuerst gut auf die veranlasste Steroidtherapie an, musste dann aber nach sechs Tagen aufgrund einer Hufrehe euthanasiert werden. Bei der Sektion wurde u.a. ersichtlich, dass der markant dilatierte, ausführende Gallengang $(\varnothing 7 \mathrm{~cm})$ durch ein orangefarbenens, glatt-faseriges Gallengangskonkrement von lehmiger Konsistenz verlegt war. Die Analyse mittels Infrarotspektrographie ergab, dass dieses Konkrement die gleiche Zusammensetzung wie Faeces aufwies und keinerlei mineralische Bestandteile enthielt, wie sie üblicherweise in Gallengangskonkrementen beim Pferd zu finden sind. Aethiopathogenetisch vermuten wir, dass der Cholelith durch den retrograden Aufstieg von Ingesta aus dem Duodenum in den ausführenden Gallengang entstand (deshalb die Bezeichnung "Enterocholelith") und sekundär zu Cholangitis und Leberinsuffizienz führte.

Schlüsselwörter: Enterocholelith, Zusammensetzung von Faeces, Cholangitis, Leberinsuffizienz, Steroidtherapie

A 15 year old Appaloosa mare was referred to the equine clinic with signs of hepatic insufficiency. Born in Canada, imported as a three year old to Switzerland, she suddenly came down with signs of jaundice a month prior to the referral. Haematological and serum biochemical abnormalities at that time were as follows: elevated sedimentation rate, hyperbilirubinemia (Fig. 1) and 2 to 3 fold elevated serum activities of alkaline phosphatase (AP), glutamate dehydrogenase (GD) and $\gamma$-glutamyltransferase ( $\gamma$-GT) (Tschudi 1981), (Fig. 2).

On referral the mare was inappetent, showed discomfort and increased salivation. The nonpigmented skin of upper and lower lip, the oral and nasal mucous membranes and the sclerae were icteric. Rectal temperature and heart rate were within normal range, mandibular lymph nodes were enlarged and respiratory rate was increased $(20 / \mathrm{min}$.). Thoracic auscultation revealed increased inspiratory breathing sounds.
Multiple wheals, which were interpreted as urticaria were visible on neck and shoulder.

Haematology was within normal range (Colahan 1999). Serum biochemical findings included hyperbilirubinemia (direct bilirubin $66.9 \mu \mathrm{mol} / \mathrm{l}$, reference range $0-8 \mu \mathrm{mol} / \mathrm{l}$; indirect bilirubin $35.5 \mu \mathrm{mol} / \mathrm{l}$ reference range $10-34 \mu \mathrm{mol} /$ ) and elevated activities of sorbitdehydrogenase (SDH $15 \mathrm{IU}$, reference range 1.9 - $5.8 \mathrm{IU}), \mathrm{AP}(2163 \mathrm{IU}$, reference range $0-228 \mathrm{IU}), \mathrm{GD}(370 \mathrm{IU}$, reference range $0-14 \mathrm{IU})$ and $\gamma$ GT (848 IU, reference range 0 - 25 IU) (see figure 2). Sulfobromophtalein clearance was increased (tfi $12.5 \mathrm{~min}$, reference range 3.5 - $4.5 \mathrm{~min}$ (Robinson 1992).

Based on the clinical and serum biochemical findings, especially the fraction of direct bilirubin, which exceeded 20 $30 \%$ of the total bilirubin, cholangiohepatitis due to choleli- 
thiasis (Gerros et al. 1993) was suspected. However biliary damage and hepatic insufficiency due to pyrrolizidine toxicity (Pearson 1991), mycotoxicosis (Colahan 1999) liver fluke or neoplasia could not be ruled out at that time. Initial therapy consisted of the intravenous application of $1 \mathrm{mg} / \mathrm{kg}$ prednisolone ${ }^{1}$

On day 2 the mare's general condition was better, ptyalism had ceased, heart and respiratory rate were the same. The mare was less icteric when compared to day 1, the total bilirubin was elevated due to a marked increase of the conjugated bilirubin, where as the unconjugated bilirubin was decreased (Fig 1). Serum activities showed a slight increase (Fig 2). Serum titers for leptospirosis sp., ehrlichiosis, babesiosis equi and caballi and for EIA (Coggins) all were negative.

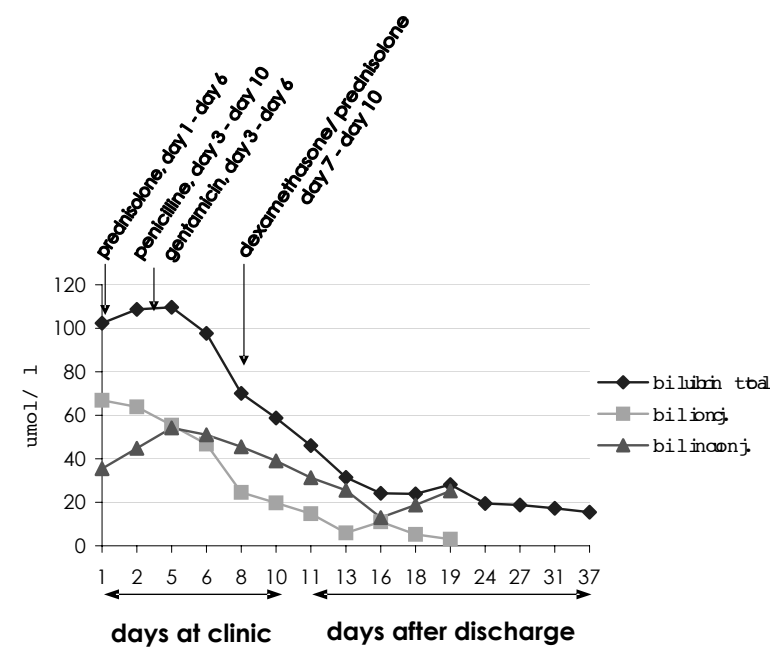

Fig 1 Serum concentration of total bilirubin, its conjugated and unconjugated fraction from day 1 to day 37 .

Konzentrationen des Gesamt-Bilirubin, des konjugierten und unkonjugierten Bilirubins im Serum von Tag 1 bis Tag 37.

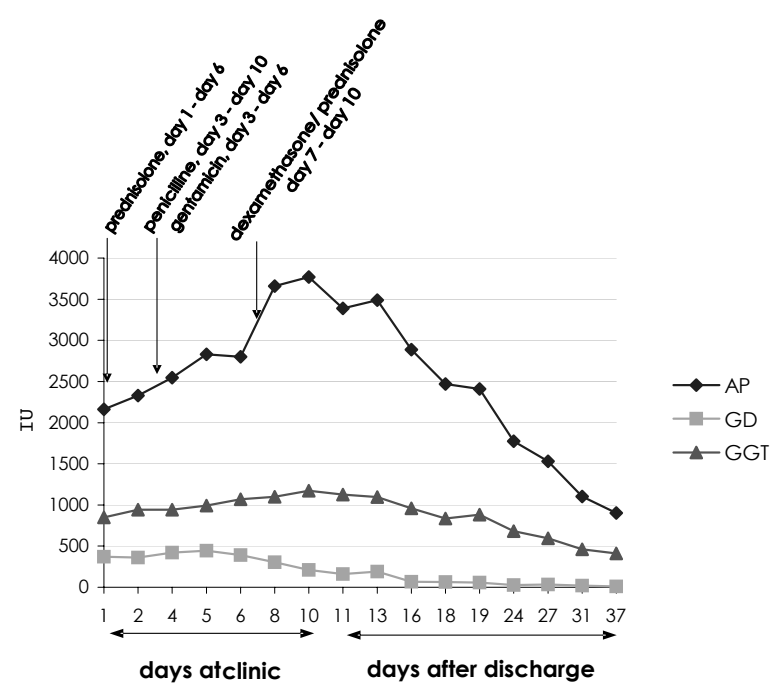

Fig 2 Serum activity of AP, GD and GGT from day 1 to 37. Enzymaktivität von AP, GD, und GGT im Serum von Tag 1 bis Tag 37.

Parasitogical examination of feces (flotation, sedimentation, bearmann-trichter) only revealed few strongyle eggs but no fasciola hepatica. Prednisolone ${ }^{1}$ therapy $(1 \mathrm{mg} / \mathrm{kg}$ once a day) was continued for five days.
On day 3 the mare had an elevated body temperature 38.9 $\left.{ }^{\circ} \mathrm{C}\right)$, which already returned back to normal the next day. She was showing some appetite, eating hay, grass and small amounts of grain. The symptoms and the urticaria were still apparent. As a result of the corticosteroid therapy the mare showed a marked leucocytosis $(18.8 \mathrm{G} / \mathrm{L}$, range 6 - $12 \mathrm{G} / \mathrm{L})$ due to an increase of segmented $(12 \mathrm{G} / \mathrm{L}$, range $3-6 \mathrm{G} / \mathrm{L})$ and unsegmented neutrophils $(3.95 \mathrm{G} / \mathrm{L}$, range $0-0.1 \mathrm{G} / \mathrm{L})$. Antimicrobial therapy was initiated by giving $30000 \mathrm{IU} / \mathrm{kg}$ penicillin ${ }^{2} \mathrm{im}$ twice a day for eight days and $3.3 \mathrm{mg} / \mathrm{kg}$ gentamicin ${ }^{3}$ iv twice a day for four days to protect the steroid therapy.

Urinalysis revealed mild glucosuria $(+$ of +++$)$, moderate to severe bilirubinuria $(++(+)$ of +++$)$, negative bacteriologi-

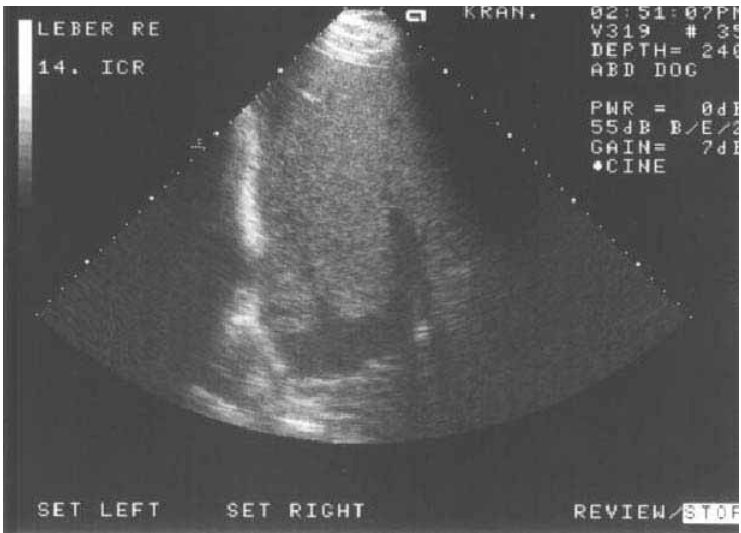

Fig 3 Dilated hepatic ducts (anechogenic structures). Dilatierte Gallengänge (anechogene Strukturen).

cal culture and negative direct fluorescent leptospiral antibody staining.

Ultrasound of the liver was performed from the right side. It revealed several tubular structures, which were considered to be dilated hepatic ducts (Fig. 3). Within one of the hepatic

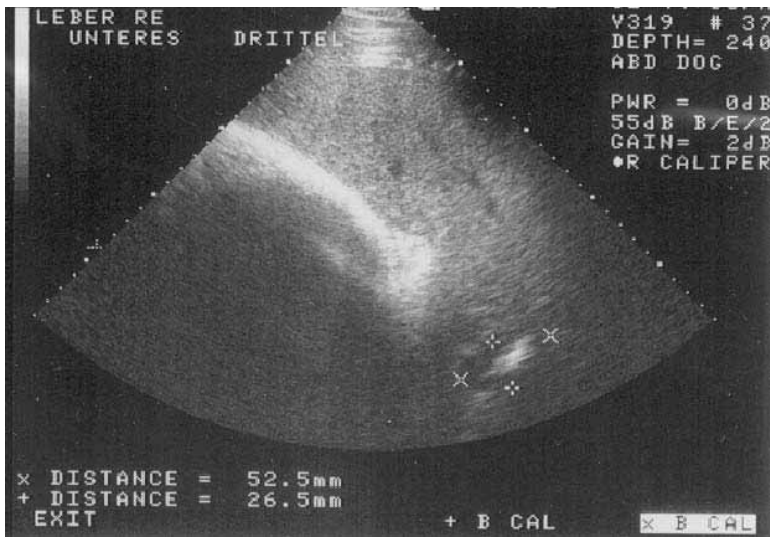

Fig 4 Echogenic structure, presumably the entero-cholelith and distended hepatic duct.

Echogene Struktur vermutlich der Entero- Cholelith und dilatierter Gallengang.

ducts an echoic structure was visualized and interpreted as cholelith (Fig. 4). Multiple calculi or another large cholelith were suspected considering the marked biliary distention and the fact that the echoic structure visualized was not obstruc- 
ting the bile duct. Based on these findings the diagnosis cholelithiasis/cholangitis causing hepatic insufficiency was made.

From the 7th day on, the general condition improved daily. The mare became brighter, had good appetite and the wheals on shoulder and neck disappeared. The skin, mucous membranes and sclerae returned back to its normal colour corresponding with the decrease of bilirubinemia, especially the fraction of conjugated bilirubin. For the first time its concentrations were clearly lower than that of unconjugated bilirubin (Fig. 1). Gentamicin administration was discontinued and corticosteroid therapy was changed to $0.02 \mathrm{mg} / \mathrm{kg}$ dexamethasonentrimethylacetate and $0.06 \mathrm{mg} / \mathrm{kg}$ prednisolone once a day for four days, with regard to the longer lasting action of the drug.

On the day 10 the mare left the clinic in good general condition. Haematological parameters and serum biochemistral activities were followed up on day 37, where all the biochemical abnormalities were back to normal except for the $\gamma$-GT (Fig. 2).

Three years later the mare was again referred to the clinic. She showed the same acute symptoms as at the first time and the serum activities of AP, GD and $\gamma$-GT were 12-, 20- and 35 -fold elevated respectively. At first she responded well to the steroid therapy but after six days, she started to suffer from drug induced laminitis and therefore was euthanized.

On post mortem examination the liver tissue showed a distinct lobular architecture and was of firm consistence and yellowgrey discoloration (figure 5). The common bile duct was markedly dilated $(\varnothing 7 \mathrm{~cm})$ and obstructed by an orange coloured, smooth - fibrous textured cholelith of loamy consistency (Fig. 6).

Histology revealed fibrosis of central vein areas with isolated inflammatory cell infiltration, proliferation of connective tissue between the sheet of hepatocytes, bridging fibrosis of periportal area with bile duct proliferation and infiltration of macrophages storing bile-pigment, in the area of the common bile duct villous hyperplasia of the epithelium, proliferation of connective tissue in the wall of the bile duct and lymphoplasmacellular infiltration.

Histology of the hoof corium revealed marked signs of acute inflammation such as hyperemia, edematous swelling and infiltration with neutrophile granulocytes. Bacteriological and parasitological examination of the liver tissue all were negative.

The analysis of the concrement by infrared spectrography revealed that it had the same composition as feces. Unlike the majority of the calculi in horses no mineral components, such as calcium bilirubinate, calcium phohashate or cholesterol could be detected (Johnston et al. 1989).

Clinical signs of hepatic disease and insufficiency are highly variable and non-specific, depending on the extent and the duration of hepatic insufficiency. The most common clinical signs are icterus, weight loss and neurological signs of hepatic encephalopathy. Intermittent abdominal pain is also a consistent feature in association with liver disease (West 1996), however, it did not occur in the present case. This is quite remarkable, considering the size of the concrement and the subsequent cholestasis. Skin disorders secondary to hepatopathy is well known. In horses dermatitis of unpigmented and unprotected skin regions in cases of chronic or acute liver failure is caused by secondary photosensitization, e.g. in association with pyrrolizidine alkaloid toxicity. Fasciola hepatica occasionally may infect horses and clinical signs include urticaria (Owen 1977). Lymphosarcoma, a neoplasm of horses arising from lymphocytes often affects the liver but also might be associated with cutaneous lesions (Lloyd 2003). In humans various skin disorders are described in association with viral infections. Dermatological disorders associated with hepatitis $A$ and $C$ virus infection include among others erythema multiforma and unticaria [Daoud et al. 1995, Scully and Ryan 1993)]. However, we only can speculate, whether a

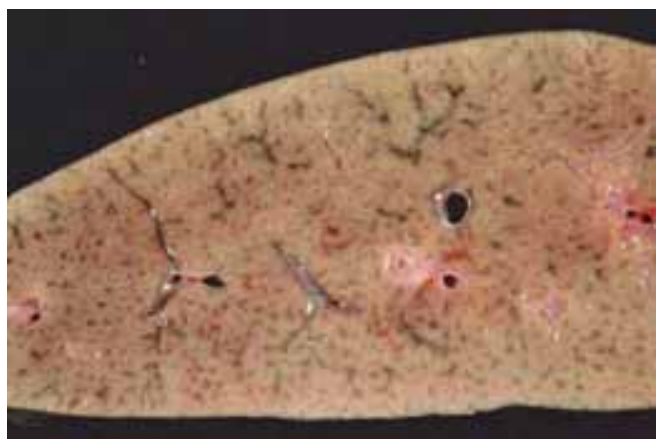

Fig 5 Cross section of the liver with firm consistence and yellow-grey discoloration.

Leberschnitt mit fester Gewebekonsistenz und gelb-graver Verfärbung.

causative association between urticaria and hepatopathy exists in the present case.

The primary, initiating factor for cholelith formation in horses is not known, yet several theories exist, including bile stasis

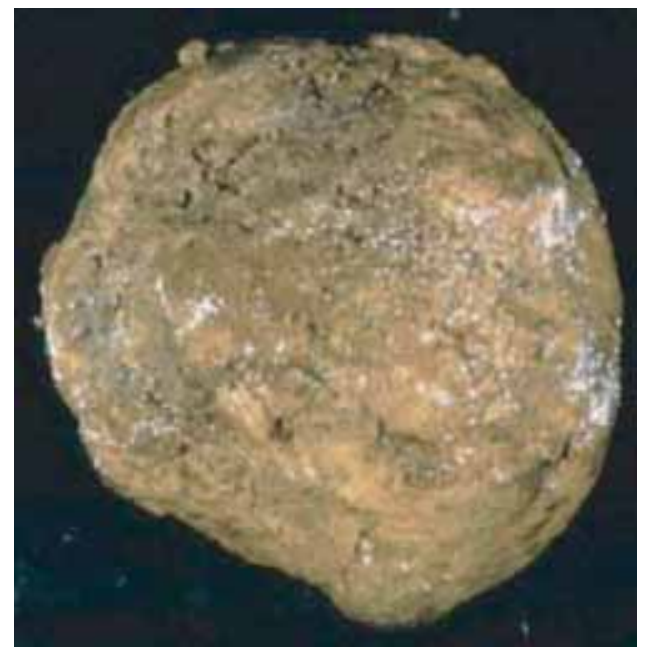

Fig 6 Orange coloured, smooth - fibrous textured enterocholelith of loamy consistence with a diameter of around $7 \mathrm{~cm}$ Orangefarbener, feinfaseriger Enterocholelith mit lehmiger Konsistenz

secondary to inflammation due to parasite migration (Colahan 1999), bile stasis secondary to ascending gram-negative infection, alterations in bile composition and nidus formation from foreign body presence in the biliary tree (Gerros et al 
1993). The majority of choleliths in horses are smooth - textured, green - brown in colour and consist of calcium bilirubinate, cholesterol and mixed bile pigments (Johnston et al. 1989). It is believed that the precipitation of bilirubin in bile is due to the transformation of soluble conjugated bilirubin to unconjugated bilirubin by B-glucuronidase which then combines with calcium to calcium bilirubinate. In humans elevated bile concentration of $\beta$-glucuronidase was found in combination with bacterial cholangitis (Ko and Lee 1999). Based on the pathophysiology in men, the facts that the majority of choleliths in horses are composed of calcium bilirubinate and that many of theses horses have documented bacterial cholangitis, it seems likely that bacterial cholangitis in horses is the underlying problem for cholelith formation (Reed and Bayly 1998).

However, in the present case the concrement had the composition of ingesta and none of the mineral components normally found in choleliths of horses. The reasons for its formation only could be speculated. A mechanical problem of the small intestines distal to bile duct opening might lead to reflux of ingesta into the biliary tree as described in foals with duodenal ulcers and small intestinal obstruction (Divers et al. 1983) and in three adults horses with suppurative cholangiohepatitis and enteritis, respectively (Davis and Jones 2003). In the present case these pathophysiological mechanisms seemed unlikely, since the mare never had a history of small intestinal disorder.

We assume that the feeding material ascended through gastrointestinal motility into the biliary system, where it possibly acted as a nidus, similar to the cholelith formation attributable to a wooden piece (Gerros et al. 1993). Therefore in the present case it would be more appropriate to refer to the concrement as enterocholelith instead of cholelith. However considering that horses duodenal papilla does not prevent reflux of intestinal material, it is remarkable that calculi formation in horses due to food material is described only in foals. The formation of calculi most probably is the coincidence of several factors, such as reflux of ingesta, cholesterinemia, cholangitis duodenitis and the consequent bile stasis, which in humans are well known risk factors for pigment stone formation (Ko and Lee 1999).

In conclusion we hypothesize in the present case that the enterocholelith formation through reflux of ingesta into the biliary system is the underlying problem and the cholangitis and hepatic insufficiency the consecutive problem. We would also assume that at the beginning of the disease multiple relatively small sized calculi were present, which were excreted during or after treatment period, which would explain the clinical course of disease, especially the absence of any colic signs.

\section{Manufacturer's addresses}

${ }^{1}$ Prednisolone, Ultracorten ${ }^{\circledR} \mathrm{H}$, Novartis, Switzerland

2 Benzylpenicillinum procainum, Novartis Tiergesundheit AG, Switzerland

${ }^{3}$ Gentamicin, Vetagent ${ }^{\circledR}$, Veterinaria AG, Switzerland

${ }^{4}$ Dexamethasonentrimethylacetate and prednisolone Opticortenol-S ${ }^{\circledR}$, Novartis, Switzerland

\section{Literature}

Colahan P. T. (1999): Equine medicine and surgery. 5th ed., St. Louis, Mo.: Mosby

Davis J. L. and S. L. Jones (2003): Suppurative cholangiohepatitis and enteritis in adult horses. J Vet Intern Med, 17, 583-587

Divers T. J. et al. (1983): Toxic hepatic failure in newborn foals. J Am Vet Med Assoc 183, 1407-1413

Daoud M. S. et al. (1995): Chronic hepatitis $C$ and skin diseases: a review. Mayo Clin Proc 70, 559-64

Gerros T. C. et al. (1993): Choledocholithiasis attributable to a foreign body in a horse. J Am Vet Med Assoc, 202, 301-303

Johnston J. K. et al. (1989): Cholelithiasis in horses: ten cases (19821986). J Am Vet Med Assoc 194, 405-409

Ko C. W. and S. P. Lee (1999): Gallstone formation. Local factors. Gastroenterol Clin North Am, 28, 99-115

Lloyd D. H. (2003): Practical equine dermatology. Oxford, UK Ames, lowa: Blackwell Science, lowa State Press. viii, 136

Owen J. M. (1977) Liver fluke infection in horses and ponies. Equine Vet J 9, 29-31

Pearson E. G. (1991): Liver failure attributable to pyrrolizidine alkaloid toxicosis and associated with inspiratory dyspnea in ponies: three cases (1982-1988). J Am Vet Med Assoc 198, 1651 - 1654

Reed S. M. and W. M. Bayly (1998): Equine internal medicine. Philadelphia: Saunders. xv, 1092

Robinson N. E. (1992): Current therapy in equine medicine 3. Philadelphia: Saunders. xxxiii, 847

Scully L. J. and A. E. Ryan (1993): Urticaria and acute hepatitis A virus infection. Am J Gastroenterol 88, 277-278

Tschudi P. R. (1981): [Reference values of various clinicochemical parameters in warm-blooded horses]. Schweiz Arch Tierheilkd $123,373-82$

West H. J. (1996): Clinical and pathological studies in horses with hepatic disease. Equine Vet J 28, 146-56

\section{Dr. Claudia Kleiber FVH}

Department of Clinical Veterinary Medicine

Equine Clinic

University of Berne

Länggassstrasse 124

$\mathrm{CH}-3012$ Berne

Switzerland

claudia.kleiber@knp.unibe.ch

\section{Pferdeheilkunde Forum 2004 - Berliner Fortbildungstage - Gesellschaftsprogramm}

